\title{
A STUDY OF REDUCTION FOR COMBUSTION PRODUCTS OF A GASOLINE ENGINE - ESPECIALLY EFFECTS OF MULTI COMPONENT FUEL PROPERTIES
}

\author{
Tadashige Kawakami \\ Faculty of Science and Engineering Hosei University \\ 3-7-2 Kajino-cho, Koganei, Tokyo 184-8584 Japan \\ e-mail:kawakami@hosei.ac.jp
}

\begin{abstract}
It is well known that the component proportion of gasoline varies depending on the extraction time of crude oil and the production country. Of course, there are effects of the engine performance and the emission on a little. So it is necessary to examine the effects of multi component fuel on the combustion characteristics and emissions. This study aims to examine the effects of fuel composition on the fuel properties and emission characteristics (HC, CO, NOx, etc.) by using multi component fuels in a small gasoline engine. Multi component fuels (model fuel) mixed with plural hydrocarbon compounds was used as fuel. The two kinds of main component fuel were used for the test base fuel (50 vol\% Iso-Octane and 25-vol\% Toluene). The other addition fuels were selected pure fuel (10 kinds of fuel: Iso-Octane, Toluene, Pentane, Hexane, Heptane, Octane, Di-Isobutylene, Methyl cyclohexane, P-Xylene, Ethanol), it was mixed 25 -vol\% in the base fuel. The main conclusions are as follows, 1) The HC emissions decrease with increasing the evaporation velocity of addition fuels for normal chain paraffin. 2) The CO emissions monotonically decrease with increasing excess air ratio by using multi component fuels. 3) It is possible to control the HC, CO and NOx emissions by using the fuel of 25-vol\% ethanol addition for a small gasoline engine.
\end{abstract}

Keywords: combustion products, gasoline engine, multi component fuel

\section{Introduction}

In recent year, multi component fuels have attracted attention as an environmentally substitute fuel because of exhaustion of petroleum resources and environmental issues. Of course, global environmental problems and global energy saving problems became very serious. Naturally, internal combustion engines are main causes of these have problems. So it is necessary environmentally substitute fuel to achieve low emissions and low fuel consumption for internal combustion engines. Especially, in automotive gasoline engines, low $\mathrm{HC}, \mathrm{CO}$ and $\mathrm{NO}_{\mathrm{x}}$ emissions are very much needed by using multi component fuels. Unfortunately, it is well known that the multi component fuels are effects on the fuel properties and emission characteristics for an internal combustion engine. Over the past few decades, a considerable number of studies have been conducted on these problems from the multiple points. For example, several techniques were developed for reduction of $\mathrm{HC}, \mathrm{CO}$ and $\mathrm{NO}_{\mathrm{x}}$ emissions from the gasoline and diesel engines such as EGR (Exhaust gas recirculation), lean combustion, HCCI (Homogeneous Charge Compression Ignition), blended fuels and new injection system [1-13]. However, very few attempts have been made at the wide multi component fuel by using the small gasoline engines.

As the first step in this study, experiments have been carried out to examine the effects of fuel composition on the fuel properties and emission characteristics of a small gasoline engines by using multi component fuels. Multi component fuels (model fuel) mixed with plural hydrocarbon compounds was used as fuel. The two kinds of main component fuel were used for the test base fuel (50-vol\% Iso-Octane and $25-\mathrm{vol} \%$ Toluene). The other addition fuels were selected pure fuel (10 kinds of fuel: Iso-Octane, Toluene, Pentane, Hexane, Heptane, Octane, Di-Isobutylene, Methyl cyclohexane, P-Xylene, Ethanol), it was mixed $25-\mathrm{vol} \%$ in the base fuel. 


\section{Experimental Apparatus and Procedure}

Figure 1 shows the experimental set up employed in this study. It consists of a small gasoline engine (KIPOR, KGE3.5:277cc 4 stroke) and an analyser of exhaust gas (AVL Di COM 4000: NOx: Chemiluminesence, $\mathrm{CO}$ and $\mathrm{CO} 2$ : NDIR, $\mathrm{O}_{2}$ : Zirconia).

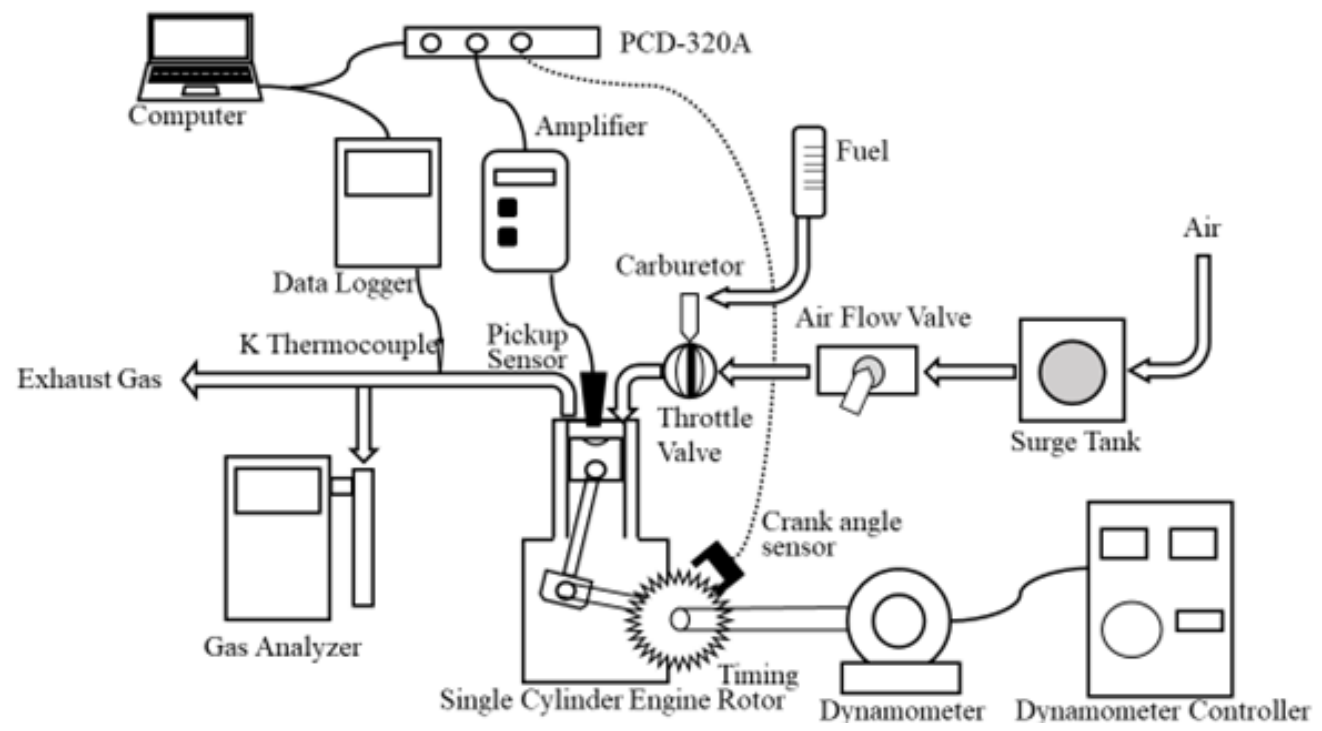

Fig. 1. Block diagram of experimental apparatus

Table 1 shows the engine specifications of the gasoline engine in this study.

Tab. 1. Engine specification

\begin{tabular}{|c|c|}
\hline Engine type & 4-stroke cycle gasoline engine \\
\hline Ignition system & T.C.I \\
\hline Cooling system & Air-cooling \\
\hline Number of cylinder & 1 \\
\hline Bore*Stroke & $78 \mathrm{~mm} * 80 \mathrm{~mm}$ \\
\hline Displacement & $277 \mathrm{cc}$ \\
\hline Valve system & OHV \\
\hline Compression ratio & 8.5 \\
\hline Maximum output & $3.0 \mathrm{~kW} / 3000 \mathrm{rpm}$ \\
\hline
\end{tabular}

Table 2 shows the fuel properties and Tab. 3, 4 show the $\mathrm{H} / \mathrm{C}$ ratio and evaporation rate for model fuels, respectively. The evaporation rate is calculated by the evaporation time from fuel drop to finished evaporation by using electric balance (METTLER TOLEDO:XP205). The volume of drop fuel is $20 \mathrm{ml}$ in this study.

Tab. 2. Fuel properties

\begin{tabular}{|l|c|c|c|c|c|c|c|c|}
\hline \multicolumn{1}{|c|}{ Fuel Properties } & Pentane & Hexane & Heptane & Octane & $\begin{array}{c}\text { Di- } \\
\text { Isobutylene }\end{array}$ & $\begin{array}{c}\text { Methyl- } \\
\text { cyclohexane }\end{array}$ & Toluene & Ethanol \\
\hline Composition & $\mathrm{C}_{5} \mathrm{H}_{12}$ & $\mathrm{C}_{6} \mathrm{H}_{14}$ & $\mathrm{C}_{7} \mathrm{H}_{16}$ & $\mathrm{C}_{8} \mathrm{H}_{18}$ & $\mathrm{C}_{8} \mathrm{H}_{16}$ & $\mathrm{C}_{7} \mathrm{H}_{14}$ & $\mathrm{C}_{7} \mathrm{H}_{14}$ & $\mathrm{C}_{2} \mathrm{H}_{6} \mathrm{O}$ \\
\hline L.H.V [MJ/kg] & 48.3 & 47.9 & 44.6 & 44.4 & 44.0 & 43.4 & 40.5 & 26.8 \\
\hline $\begin{array}{l}\text { L.H.V [MJ/kg] } \\
\text { Model Fuel (25\% } \\
\text { volume fraction) }\end{array}$ & 43.3 & 43.3 & 43.2 & 43.2 & 43.1 & 43.0 & 40.5 & 38.7 \\
\hline
\end{tabular}


Tab. 3. H/C ratio of model fuels

\begin{tabular}{|c|c|c|c|}
\hline Symbol & H/C Ratio (mole) & Symbol & H/C Ratio (mole) \\
\hline ISO & 2.250 & HEP25 & 1.912 \\
\hline TOL & 1.143 & OCT25 & 1.906 \\
\hline DI & 2.000 & DI25 & 1.850 \\
\hline ISO25 & 1.905 & MET25 & 1.852 \\
\hline TOL25 & 1.612 & XYL25 & 1.645 \\
\hline PEN25 & 1.928 & ETH25 & 2.015 \\
\hline HEX25 & 1.919 & BASE & 1.802 \\
\hline
\end{tabular}

*Base Fuel (50-vol\% Iso-Octane and 25-vol\% Toluene)

Tab. 4. Evaporation rate (initial)

\begin{tabular}{|c|c|}
\hline Symbol & Evaporation rate (Initial: $\mathrm{mg} / \mathrm{s}$ ) \\
\hline ISO25 & 0.580 \\
\hline TOL25 & 0.488 \\
\hline PEN25 & 1.330 \\
\hline HEX25 & 0.868 \\
\hline HEP25 & 0.551 \\
\hline OCT25 & 0.426 \\
\hline DI25 & 0.564 \\
\hline MET25 & 0.530 \\
\hline XYL25 & 0.432 \\
\hline ETH25 & 0.806 \\
\hline
\end{tabular}

\section{Results and discussion}

Figure 2 and 3 show the $\mathrm{HC}$ emissions against excess air ratio as a function of additional fuel without the engine load for the small gasoline engine. The additional fuel volume fraction is $25-$ vol\% (constant). The HC emissions are nearly constant under excess air ratio from 0.2 to 0.6 at any additional fuels. On the other hand, over the excess air ratio of 0.8 , additional fuel properties strong effects on the $\mathrm{HC}$ emissions. It is due to the influence of the evaporation rate and lower heating value of additional fuels.

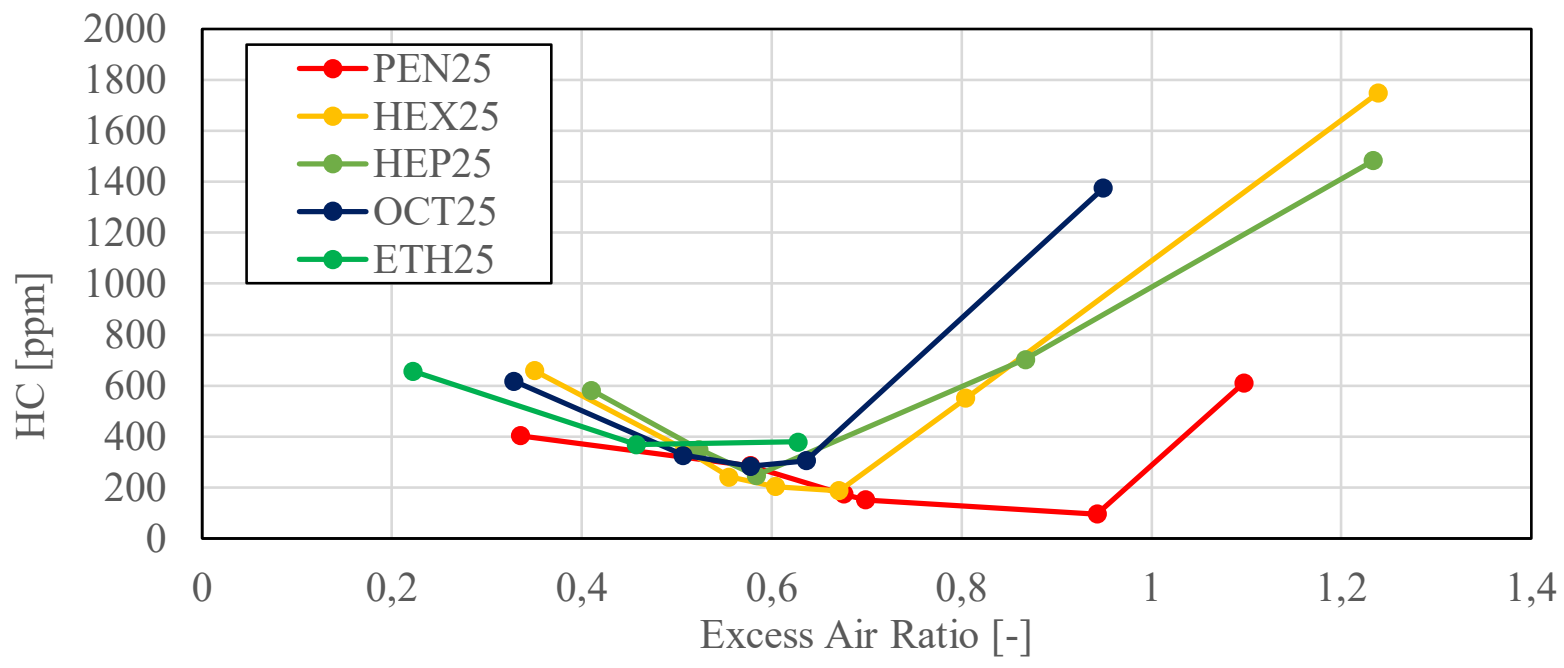

Fig. 2. HC emission (PEN25, HEX25, HEP25, OCT25, ETH25) 


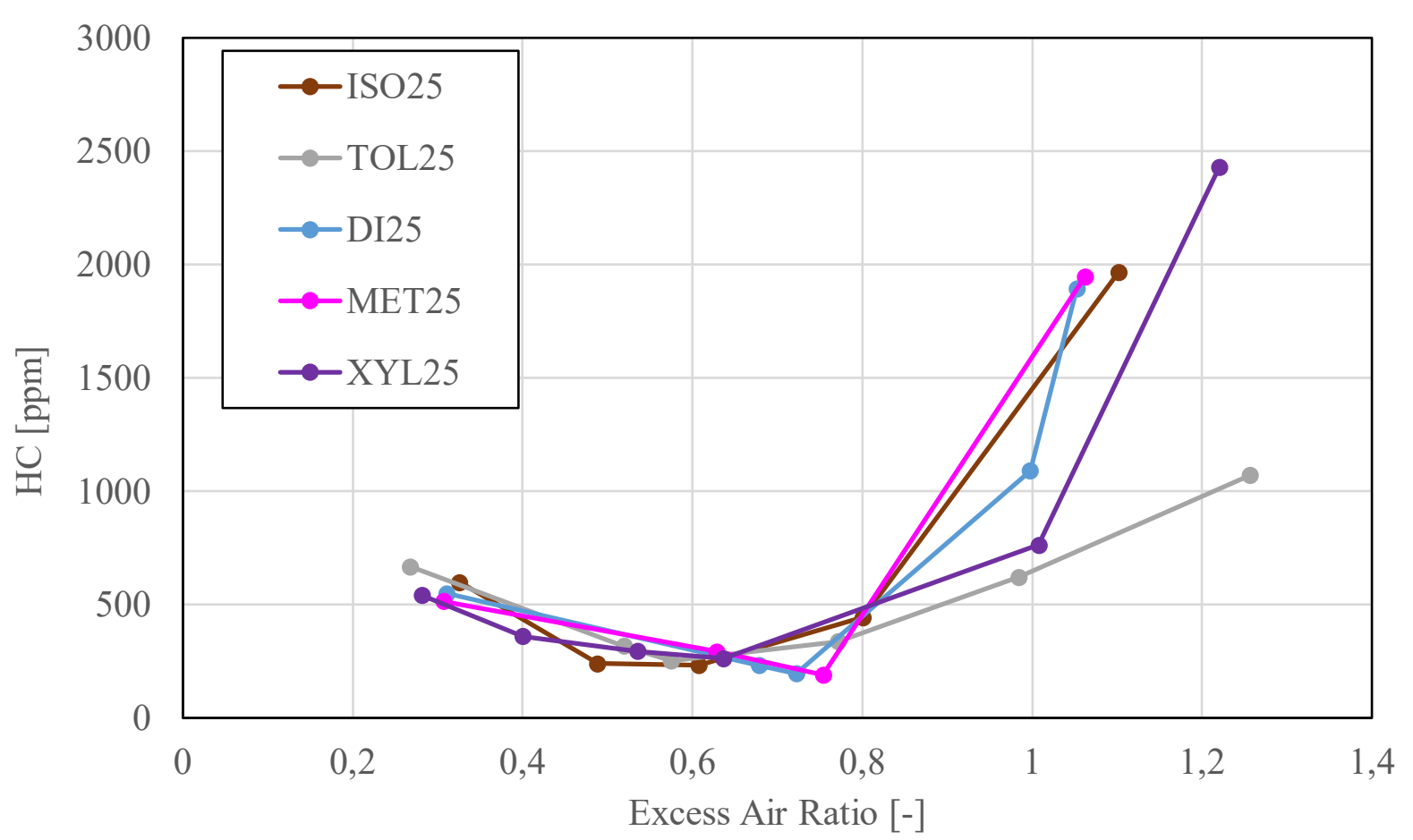

Fig. 3. HC emission (ISO25, TOL25, DI25, MET25, XYL25)

Figure 4 and 5 show the $\mathrm{CO}$ emissions against the excess air ratio as a function of additional fuel without and with low engine load for the small gasoline engine. As can be seen from these figures, $\mathrm{CO}$ emissions for all the additional fuels are almost same level at same excess ratio. Furthermore, the decreasing ratio from 10 to $0.5 \mathrm{vol} \%$ for $\mathrm{CO}$ emissions are depend on the additional fuel properties. These results indicated that, the changing of 25 -vol $\%$ fuel addition can be control the decreasing ratio of $\mathrm{CO}$ emissions near the 0.8 excess air ratio for small gasoline engines.

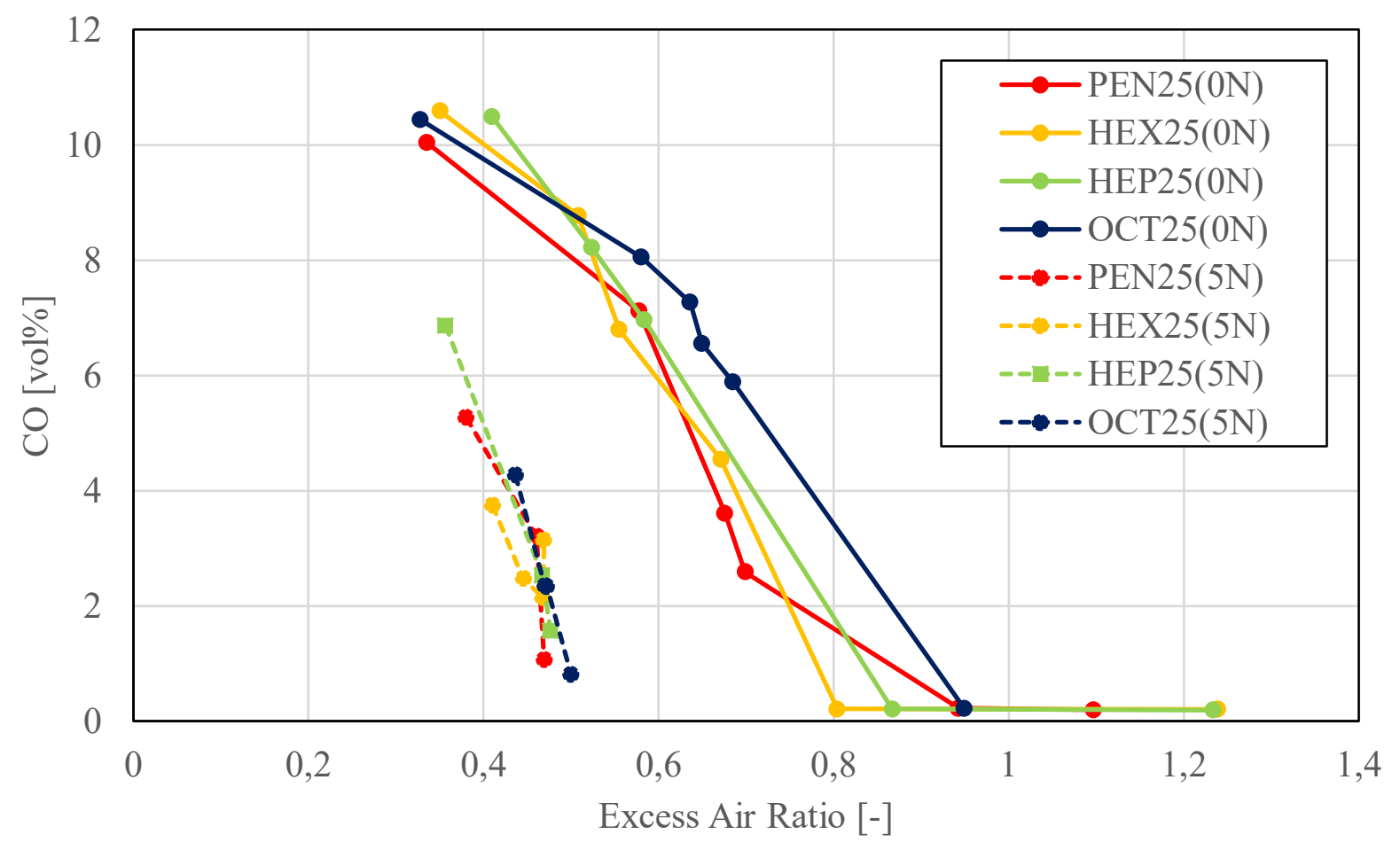

Fig. 4. CO emission (PEN25, HEX25, HEP25, OCT25) 


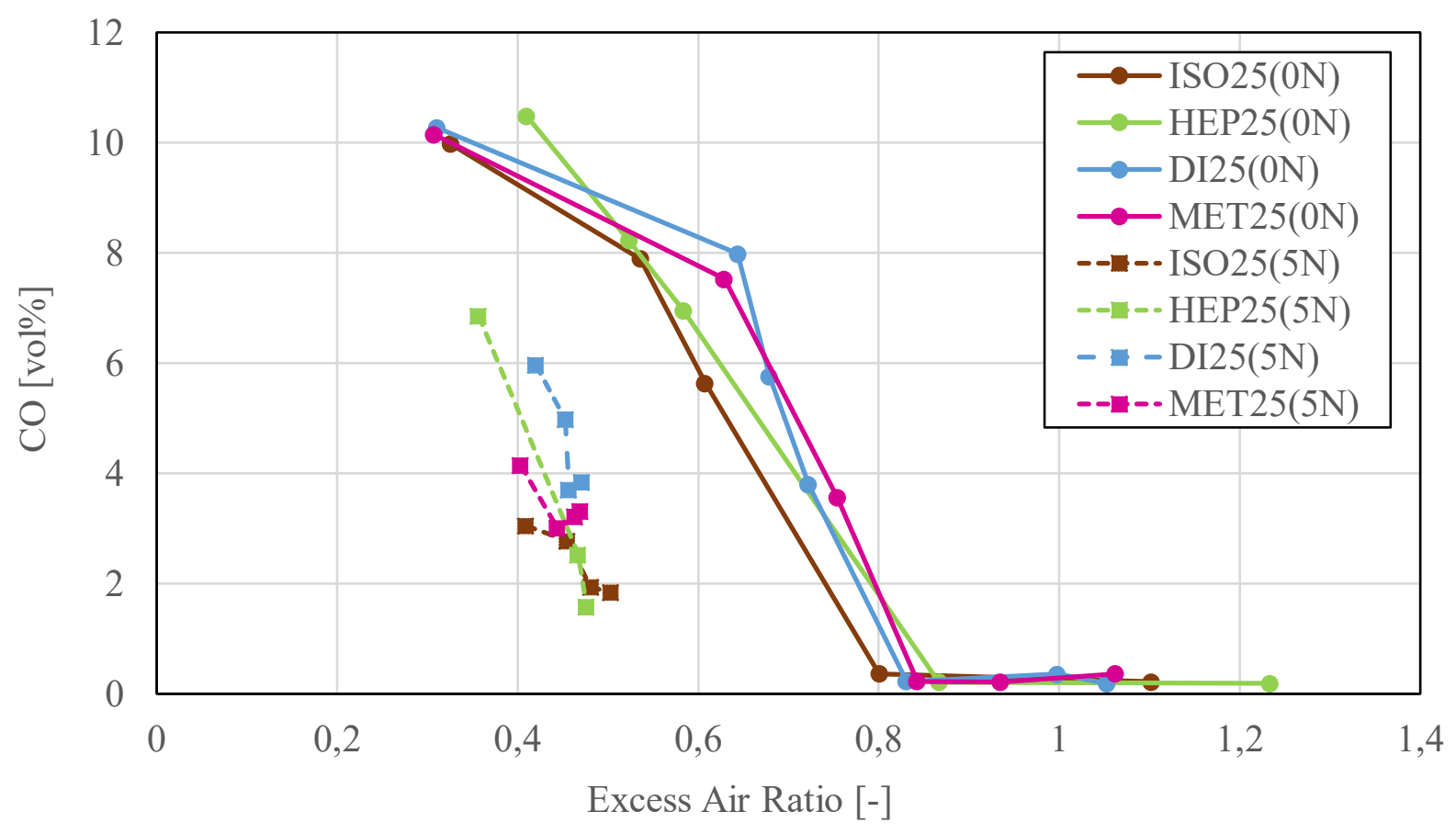

Fig. 5. CO emission (ISO25, OL25, DI25, MET25)

Figure 6 shows the $\mathrm{HC}$ emissions against fuel properties as a function of the engine revolution without engine load at constant throttle opening (20\%). As seen from this figure, the HC emissions decrease with increasing the engine revolution without ISO and TOL fuel addition. Furthermore, the amount of the $\mathrm{HC}$ emissions of ethanol is smaller than that of the other fuel additions without the TOL. It is causes by the effects of the included oxygen for ethanol addition.

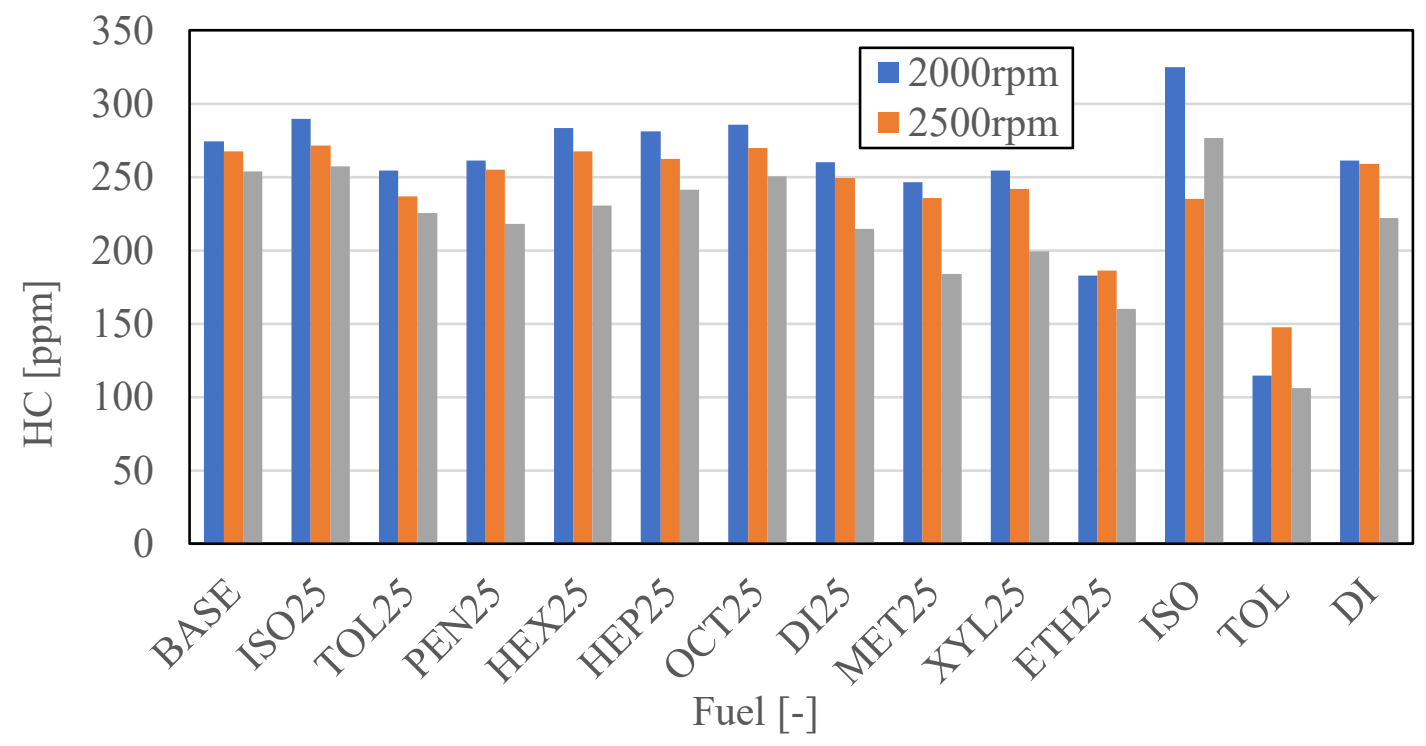

Fig. 6. HC emission (20\%)

Figure 7 shows the $\mathrm{CO}$ emissions against fuel properties as a function of the engine revolution without engine load at constant throttle opening (20\%). From this figure, it can be seen that the CO emissions of TOL addition fuels are bigger than that of other fuel additions. Furthermore, it is interesting fact that the $\mathrm{CO}$ emissions of ethanol are smaller than that of the other fuel additions. This fact indicated that the ratios of oxygen and hydrocarbon in the fuel are very important role for simultaneous reduction of $\mathrm{HC}$ and $\mathrm{CO}$ emissions for small gasoline engine. 


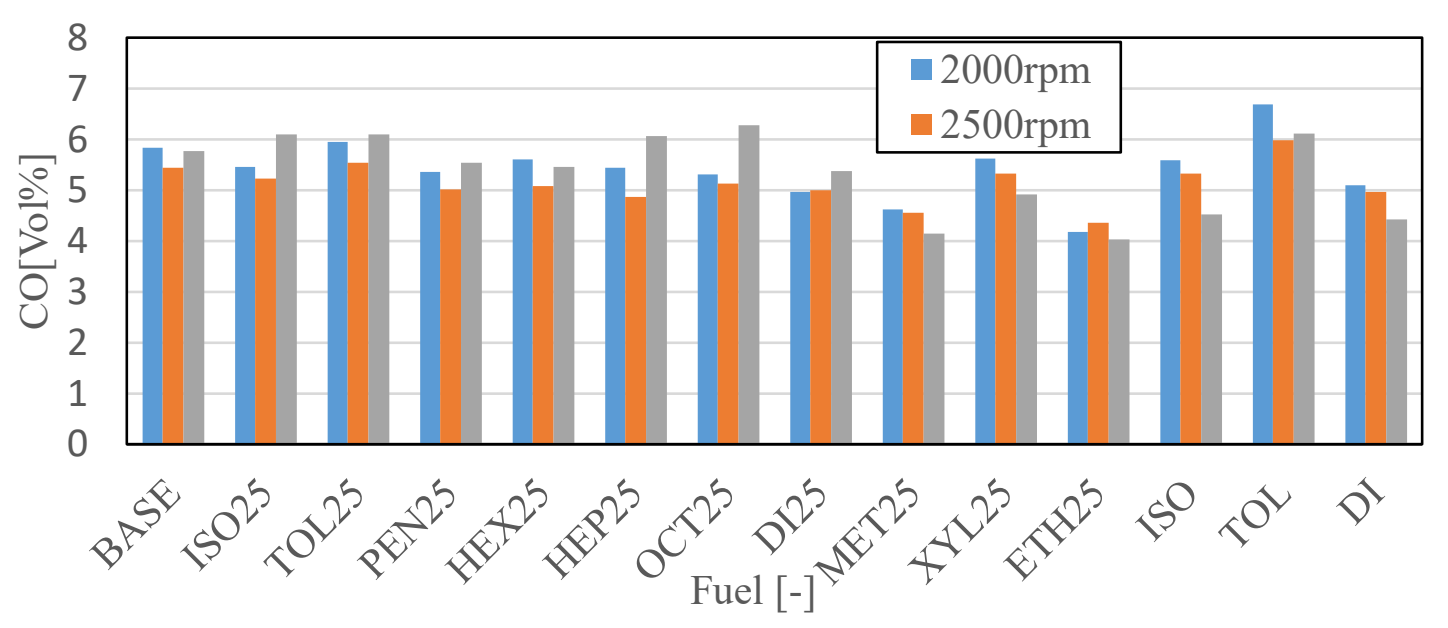

Fig. 7. CO Emission (20\%)

Figure 8 shows the NOx emissions against the additional fuel properties as a function of engine revolution without engine load at constant throttle opening (20\%). From this figure, it can be seen that NOx emission of TOL is bigger than that of other additional fuel at any engine revolutions. It is caused by increasing the flame temperature by the addition of TOL.

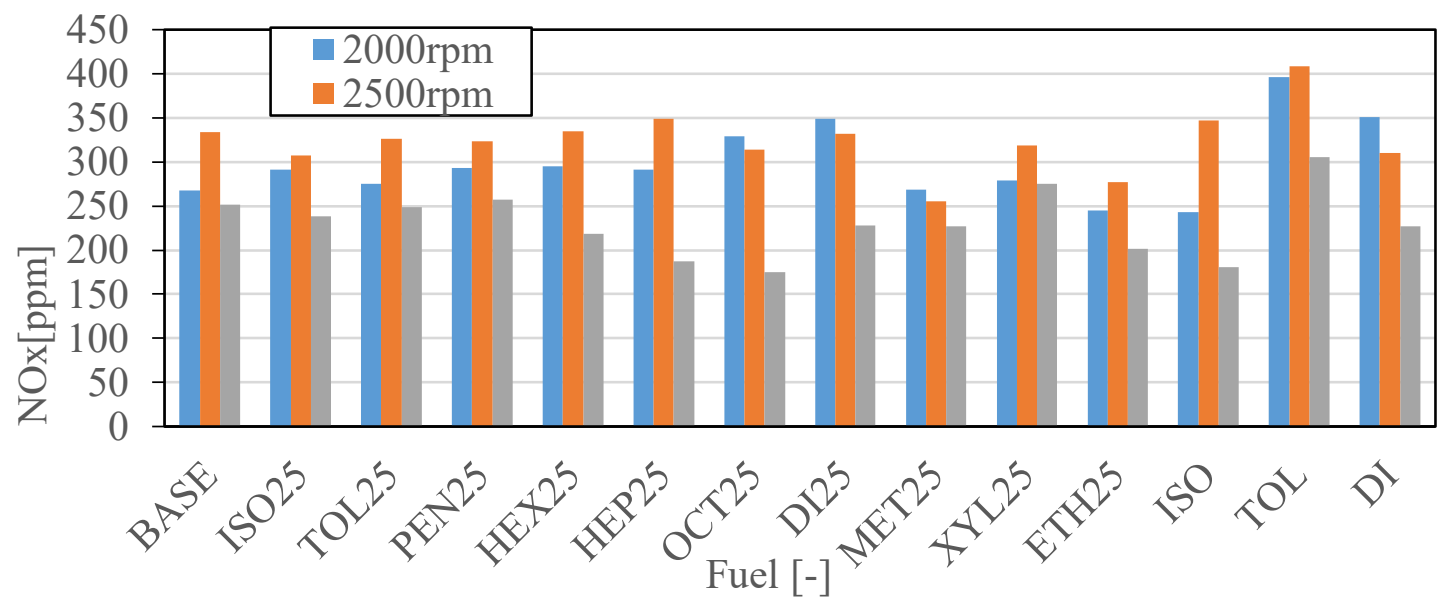

Fig. 8. $\mathrm{NO}_{X}$ Emission (20\%)

\section{Conclusions}

Experiments have been carried out to examine the effects of fuel composition on the fuel properties and emission characteristics $(\mathrm{HC}, \mathrm{CO}, \mathrm{NOx})$ by using multi component fuels in a small gasoline engine. The main conclusions are as follows:

1) The $\mathrm{HC}$ emissions decrease with increasing the evaporation rate of addition fuels for normal chain paraffin.

2) The $\mathrm{CO}$ emissions monotonically decrease with increasing excess air ratio by using multi component fuels.

3) It is possible to control the HC, CO and NOx emissions by using the fuel of $25-\mathrm{vol} \%$ ethanol addition for a small gasoline engine.

\section{References}

[1] Iijima, A., Shoji, H., A study of HCCI combustion characteristics using Spectroscopic Techniques, SAE paper 2007-01-1886, 2007. 
[2] Tsutsumi, Y., Hoshina, K., Iijima, A., Shoji, H., Analysis of the combustion characteristics of HCCI Engine operationg on DME and Methane, SAE Paper No.2007-32-0041, 2007.

[3] Lim, O. T., et al., The fuel unmixedness effect on DME HCCI combustion using rapid compression and expansion machine, SAE Paper No.2007-42-0042, 2007.

[4] Daisho, Y., et al., Contolling combustion and exhaust emissions in a direct-injection diesel engine dual-fueled with natural gas, SAE Paper, No.952436, 1995.

[5] Tomita, et al., Effects of EGR and early injection of diesel fuel on combustion characteristics and exhaust emissions in a methane dual fuel engine, SAE paper, No.2002-01-2723, 2002.

[6] Hill, P. G., et al., NOx reduction from heavy-duty diesel engine with direct injection of natural gas and cooled exhaust gas recirculation, International Journal of Engine Research, Vol. 5, No. 2, pp. 175-191, 2003.

[7] Tomita, et al., Combustion characteristics and performance of supercharged micro-pilot natural gas engine, Proceedings of FISITA 2006 World Automotive Congress, Paper No. F2006p230, pp. 1-10, 2006.

[8] Ozaki, J., Iida, N., Effect of Degree of Unmixedness on HCCI Combustion Based on Experiment and Numerical Analysis, SAE Paper 2006-32-0046, 2006.

[9] Sugiyama, H., Kawakami, T., Influence of blend fuels on combustion characteristics for small diesel engine, Small Engine Technology Conference SAE of Japan and SAE International, 20076523/2007-32-0023, 2007.

[10] Kawakami, T., Combustion characteristics for small diesel engine by using emulsified blend fuels of vegetable oil and light oil, Journal of KONES Powertrain and Transport, Vol. 18, No. 4, pp. 185-190, 2011.

[11] Kawakami, T., A study of emission reduction by using alcohol blend fuel for small diesel engine, Journal of KONES Powertrain and Transport, Vol. 21, No. 1, pp. 125-130, 2014.

[12] Kawakami, T., Experimental study of emission reduction by using alcohol blended fuel for small gasoline engine, Journal of KONES Powertrain and Transport, Vol. 22, No. 2, pp. 115-120, 2015.

[13] Kawakami, T., The influence of injection timing on the combustion characteristics for the heterogeneous combustion field using impinging injection, Journal of KONES Powertrain and Transport, Vol. 25, No. 3, pp. 283-288, 2018. 